\title{
Distributions of low molecular weight dicarboxylic acids, ketoacids and $\alpha$-dicarbonyls in the marine aerosols collected over the Arctic Ocean during late summer
}

\author{
K. Kawamura ${ }^{1}$, K. Ono ${ }^{1}$, E. Tachibana ${ }^{1}$, B. Charriére ${ }^{2}$, and R. Sempéré ${ }^{2}$ \\ ${ }^{1}$ Institute of Low Temperature Science, Hokkaido University, Sapporo 060-0819, Japan \\ ${ }^{2}$ Aix-Marseille University, Mediterranean Institute of Oceanography (MIO), 13288, Marseille, Cedex 9; Université du Sud \\ Toulon-Var, MIO, 83957, La Garde Cedex, France, CNRS/INSU, MIO UMR7294; IRD, MIO UMR235, France \\ Correspondence to: K. Kawamura (kawamura@lowtem.hokudai.ac.jp)
}

Received: 30 June 2012 - Published in Biogeosciences Discuss.: 2 August 2012

Revised: 25 October 2012 - Accepted: 1 November 2012 - Published: 22 November 2012

\begin{abstract}
Oxalic and other small dicarboxylic acids have been reported as important water-soluble organic constituents of atmospheric aerosols from different environments. Their molecular distributions are generally characterized by the predominance of oxalic acid $\left(\mathrm{C}_{2}\right)$ followed by malonic $\left(\mathrm{C}_{3}\right)$ and/or succinic $\left(\mathrm{C}_{4}\right)$ acids. In this study, we collected marine aerosols from the Arctic Ocean during late summer in 2009 when sea ice was retreating. The marine aerosols were analyzed for the molecular distributions of dicarboxylic acids as well as ketocarboxylic acids and $\alpha$ dicarbonyls to better understand the source of water-soluble organics and their photochemical processes in the high Arctic marine atmosphere. We found that diacids are more abundant than ketoacids and $\alpha$-dicarbonyls, but their concentrations are generally low $\left(<30 \mathrm{ng} \mathrm{m}^{-3}\right)$, except for one sample (up to $70 \mathrm{ng} \mathrm{m}^{-3}$ ) that was collected near the mouth of Mackenzie River during clear sky condition. Although the molecular compositions of diacids are in general characterized by the predominance of oxalic acid, a depletion of $\mathrm{C}_{2}$ was found in two samples in which $\mathrm{C}_{4}$ became the most abundant. Similar depletion of oxalic acid has previously been reported in the Arctic aerosols collected at Alert after polar sunrise and in the summer aerosols from the coast of Antarctica. Because the marine aerosols that showed a depletion of $\mathrm{C}_{2}$ were collected under the overcast and/or foggy conditions, we suggest that a photochemical decomposition of oxalic acid may have occurred in aqueous phase of aerosols over the Arctic Ocean via the photo dissociation of oxalate-Fe (III) complex. We also determined stable carbon isotopic compositions $\left(\delta^{13} \mathrm{C}\right)$
\end{abstract}

of bulk aerosol carbon and individual diacids. The $\delta^{13} \mathrm{C}$ of bulk aerosols showed $-26.5 \%$ (range: -29.7 to $-24.7 \%$ ), suggesting that marine aerosol carbon is derived from both terrestrial and marine organic materials. In contrast, oxalic acid showed much larger $\delta^{13} \mathrm{C}$ values (average: $-20.9 \%$, range: $-24.7 \%$ o to $-17.0 \%$ ) than those of bulk aerosol carbon. Interestingly, $\delta^{13} \mathrm{C}$ values of oxalic acid were higher than $\mathrm{C}_{3}$ (av. $-26.6 \%$ ) and $\mathrm{C}_{4}(-25.8 \%$ o) diacids, suggesting that oxalic acid is enriched with ${ }^{13} \mathrm{C}$ due to its photochemical processing (aging) in the marine atmosphere.

\section{Introduction}

Low molecular weight dicarboxylic acids are one of the most abundant organic compound classes in atmospheric aerosols. They were reported in the urban (Kawamura and Ikushima, 1993; Sempéré and Kawamura, 1994; Rohrl and Lammel, 2001; Wang et al., 2002; Yao et al., 2002; Rompp et al., 2006; Kitanovski et al., 2011), mountainous (Legrand et al., 2007), marine (Kawamura and Sakaguchi, 1999; Mochida et al., 2003a, b), and Arctic and Antarctic atmospheres (Kawamura et al., 1996a, b, 2005; Narukawa et al., 2002, 2003). Due to their water-soluble properties, diacids as well as ketoacids and $\alpha$-dicarbonyls can act as cloud condensation nuclei $(\mathrm{CCN})$ and hence influence the Earth's radiative forcing and climate (Kawamura and Usukura, 1993; Saxena et al., 1995; Saxena and Hildemann, 1996). These compounds can be directly emitted by fossil fuel combustion (Kawamura and 
Kaplan, 1987) and biomass burning (Legrand and de Angelis, 1996; Narukawa et al., 1999; Kundu et al., 2010b). However, a major portion of diacids is photochemically produced by photochemical oxidation of organic precursors in the atmosphere (Kawamura et al., 1996a; Warneck, 2003; Ervens et al., 2004; Kawamura and Yasui, 2005; Carlton et al., 2007).

Dicarboxylic acids and other water-soluble organic compounds account for 1-2\% of organic carbon in urban aerosols (Kawamura and Ikushima, 1993) and up to $16 \%$ in remote marine aerosols (Kawamura and Sakaguchi, 1999). Thus, they can potentially play an important role in the CCN activity of atmospheric particles although inorganic ions such as sulfate may have more influence on the $\mathrm{CCN}$ activity. In addition to dicarboxylic acids, however, there are significant amounts of water-soluble organic compounds (WSOC), whose chemical structures including HULIS (humic-like substances) are still not known (Ervens et al., 2011). In contrast, diacids and related compounds can serve as organic tracers to understand photochemical processing of WSOC possibly in aqueous aerosol phase (e.g., Sorooshian et al., 2006; Ervens et al., 2011). Because photochemical processing of organics in wet aerosols can alter the organic aerosol mass and properties, the studies of diacids and related compounds can represent proxies that are routinely measured for a possibly larger fraction of the aerosols and thus such studies can lead to better understanding of the underlying processes in aqueous aerosols (Cunningham et al., 1988; Faust and Zepp, 1993; Ervens et al., 2011).

The studies of Arctic aerosols demonstrated that the atmospheric pollutants such as sulfate are long-range transported from mid-latitudes to the Arctic maximizing in winter to spring seasons (Barrie, 1986, 1997). In the High Arctic Alert $\left(82.5^{\circ} \mathrm{N} ; 62.3^{\circ} \mathrm{W}\right)$, concentrations of dicarboxylic acids have been reported to increase from winter to spring with maxima at polar sunrise in spring due to photochemical production and then decrease toward the summer (Kawamura et al., 1996a, 2005). The analyses of stable carbon isotopic compositions of aerosol carbon and ionic composition of the high Arctic aerosols showed that winter aerosols are mainly derived from the primary pollutants emitted into the midlatitudes, whereas sea-to-air emissions of marine organic carbon are enhanced in the late spring to early summer following a melting of sea ice in the Arctic Ocean (Narukawa et al., 2008). However, there is no reported observation of dicarboxylic acids and related compounds in the marine aerosols from the Arctic Ocean. Recent studies predicted significant changes in the zone including the melting of sea ice due to global warming for coming decades (McGuire et al., 2009). These changes should result in a river flow increase coupled with permafrost thaws, higher coastal erosion and change in precipitation patterns modifying the organic and inorganic terrestrial inputs both by riverine and atmospheric processes. These changes will affect the primary productivity that will modify the aerosols dynamics and thus probably the radiative budget in the Arctic.

In this study, we collected marine aerosol samples from the western Arctic Ocean. We analyzed the samples for homologous series of low molecular weight dicarboxylic acids, ketocarboxylic acids and $\alpha$-dicarbonyls (glyoxal and methylglyoxal) in the marine aerosols as well as their stable carbon isotopic composition at molecular level. We also determined total carbon and nitrogen contents and their bulk isotopic compositions in the aerosol samples. Here we report for the first time the molecular compositions of dicarboxylic acids and related compounds and their stable carbon isotopic compositions in the Arctic Ocean aerosols and discuss their sources and formation processes in the High Arctic marine atmosphere.

\section{Samples and methods}

Marine aerosol samples (TSP) were collected in the Beaufort Sea of the western Arctic Ocean using a high volume air sampler (Kimoto AS-810B) and quartz fiber filters $(20 \times 25 \mathrm{~cm}$, Pallflex 2500QAT-UP) during the MALINA cruise of R/V CCGS Amundsen in 3-25 August 2009. Ten aerosol samples (\#1 to \#10) were collected during the cruise. Figure 1 shows the cruise tracks for the ten aerosol samples with sampling hours for each sample. The quartz filter was pre-combusted at $450^{\circ} \mathrm{C}$ for $6 \mathrm{~h}$ to remove organic contaminants and stored in a clean glass bottle with a Teflon-lined screw cap before the sampling. The air sampler was placed on the ship deck at ca. $20 \mathrm{~m}$ above the sea level. Aerosol sampling was conducted on a basis of 2-3 day sampling periods. The pump of the air sampler was switched on/off using a wind speed $\left(>5 \mathrm{~m} \mathrm{~s}^{-1}\right)$ and wind sector $\left( \pm 60^{\circ}\right)$ controller system to avoid a potential contamination from the ship exhaust. Flow rate of the air was 1.0 or $1.2 \mathrm{~m}^{3}$ per minute. Total air sample volume measured by a mass flow controller ranged from $105 \mathrm{~m}^{3}$ to $1909 \mathrm{~m}^{3}$ for each sample with effective pumping time of $12 \%$ to $51 \%$ of the sampling period, except for one sample (3\%, \#5 sample). Field blank was taken after the filter was placed in the air sampler without sucking air and stored in the clean glass bottle.

During sample collection, the ambient temperatures ranged from $-1.5^{\circ} \mathrm{C}$ to $9.2^{\circ} \mathrm{C}$ with an average of $3.0^{\circ} \mathrm{C}$. The presence of sea ice in the ocean frequently forced us to change the cruise tracks of the ship. The weather conditions during the cruise were frequently overcast and occasionally foggy with rare sunny conditions, however, there were no events of rain or snow during the sampling period. The atmospheric irradiance was recorded on the upper deck of the ship at 4 UV and 4 visible wavebands using OCR-504 downward irradiance sensors (Satlantic narrow band radiometers). Figure 2 shows the variations of solar radiation at $412 \mathrm{~nm}$ together with the information of sampling period for both aerosol samples and fog events. After the sample collection, 


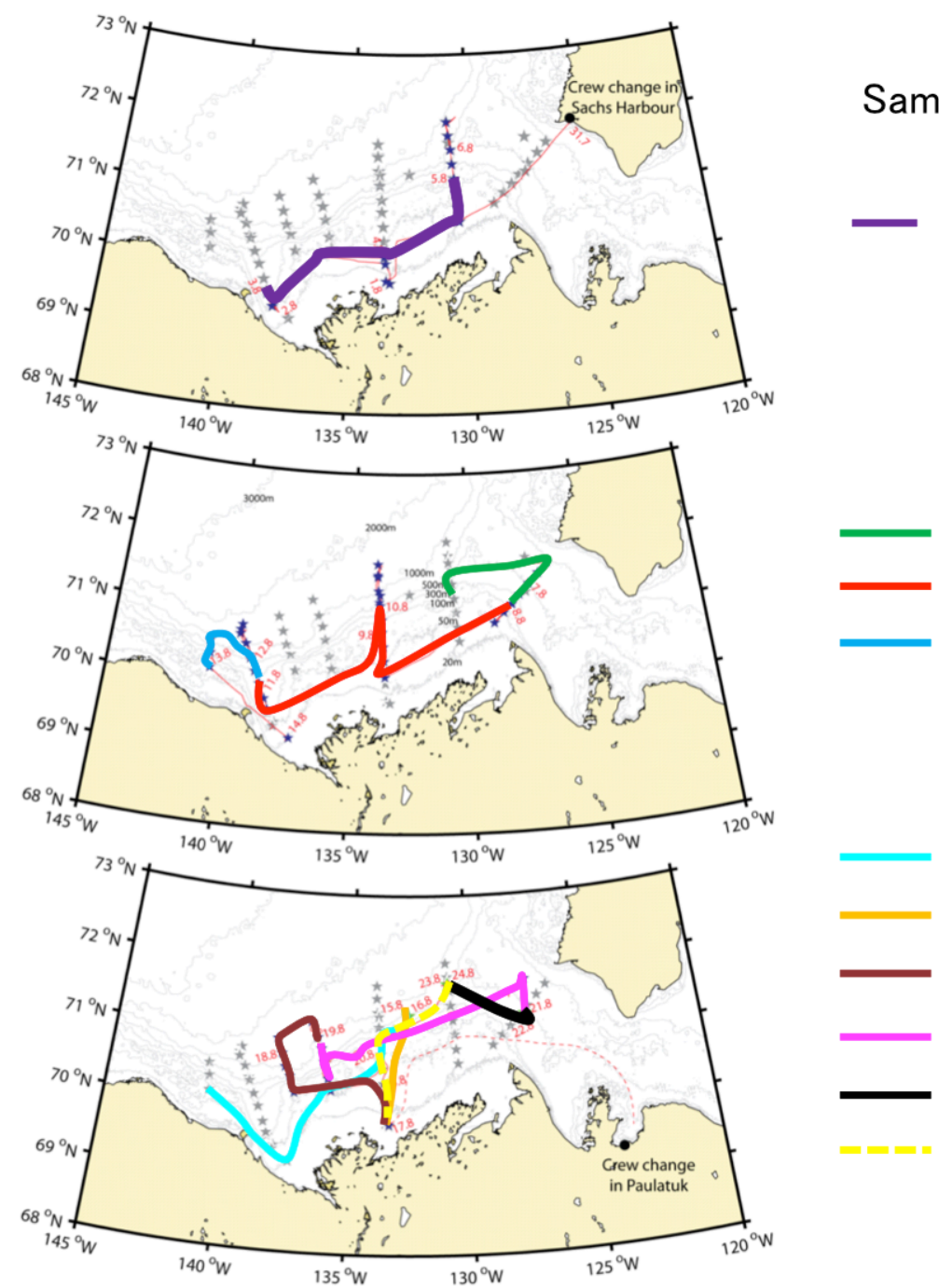

\section{Sample ID and dates (hour)}

\#1 August 3-5 (22)

\#2 August 5-8 (22)

\#3 August 8-11 (26)

\#4 August 11-13 (10)

\#5 August 13-15 (1.3)

\#6 August 15-17 (24)

\#7 August 17-19 (11)

\#8 August 19-21 (7)

\#9 August 21-23 (6)

\#10 August 23-25 (12)

Fig. 1. Map of the western Arctic Ocean and the MALINA cruise tracks for aerosol sampling. The sampling hours are given in parenthesis.

each filter sample was returned in a clean glass bottle and the Teflon-lined screw cap was tightened to avoid the exchange of the air during storage. The samples were stored in the refrigerator in the ship during the cruise and then transported to the laboratory in Sapporo, Japan, where the samples were stored in a dark freezer room at $-20^{\circ} \mathrm{C}$ prior to analysis.

Aliquots of filter samples were extracted with pure water to separate diacids and related water-soluble organic compounds. The water extracts were adjusted to $\mathrm{pH}=8.5$ using a $0.1 \mathrm{M} \mathrm{KOH}$ solution. The extracts were concentrated using a rotary evaporator under vacuum and derivatized to dibutyl esters and acetals with $14 \% \mathrm{BF}_{3}$ in n-butanol (Supelco). The derivatives were dissolved in $\mathrm{n}$-hexane and injected to a gas chromatograph (GC) and $\mathrm{GC} /$ mass spectrometer to determine dicarboxylic acids $\left(\mathrm{C}_{2}-\mathrm{C}_{10}\right)$, ketocarboxylic acids $\left(\mathrm{C}_{2}-\right.$ $\mathrm{C}_{9}$ ) and $\alpha$-dicarbonyls (glyoxal and methylglyoxal; Kawamura, 1993; Kawamura and Ikushima, 1993). GC (Agilent
6980) was installed with a split/splitless injector and HP5 column $(0.2 \mathrm{~mm} \times 25 \mathrm{~m}$, film thickness $0.5 \mu \mathrm{m})$. Recoveries of oxalic, malonic, and succinic acids were better than $84 \%$. The recoveries were improved employing the $\mathrm{pH}$ adjustment of the water extracts compared to those without the pH adjustment (e.g., $70 \%$ for oxalic acid; Kawamura and Ikushima, 1993). Field blank was analyzed as the actual samples. Although we found small peaks of oxalic acid and phthalic acid on the GC chromatogram, their amounts were less than $5 \%$ of the actual samples. The concentrations of the compounds reported here are all corrected for the field blank. Duplicate analyses of the sample showed that the analytical errors in the procedures were within $10 \%$ for major components.

Stable carbon isotopic composition of dicarboxylic and ketocarboxylic acids were determined using a $\mathrm{GC} /$ combustion/isotope ratio mass spectrometer (Finnigan 


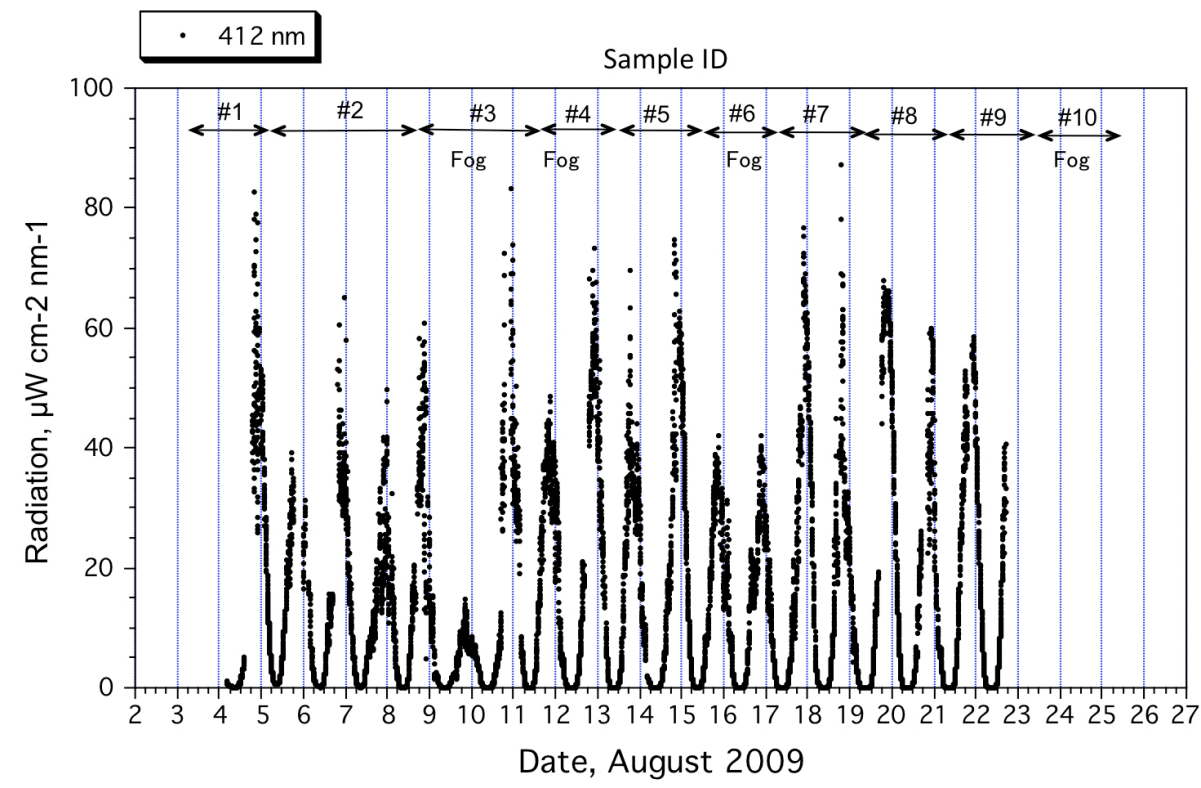

Fig. 2. Solar irradiance at UV $412 \mathrm{~nm}$ and aerosol filter ID with information of fog event.

MAT Delta plus). Details of the analytical methodology are described elsewhere (Kawamura and Watanabe, 2004). Because of the small peaks, the isotopic compositions of glyoxal and methylglyoxal could not be measured in this study.

Total carbon and nitrogen contents were also determined for the marine aerosol samples. An aliquot of filter sample was placed in a tin cup and caked in a small ball. The caked samples (filter sample plus tin cup) were then analyzed for total carbon (TC) and total nitrogen (TN) contents and their isotopic compositions $\left(\delta^{13} \mathrm{C}\right.$ and $\left.\delta^{15} \mathrm{~N}\right)$ using elemental analyzer (EA; model Carlo Erba NA 1500) and EA/isotope ratio mass spectrometer (IRMS) (Finnigan MAT Delta Plus), respectively (Kawamura et al., 2004; Narukawa et al., 2008). Acetanilide was used as an external standard to determine $\mathrm{TC}, \mathrm{TN}$, and their isotopic compositions $\left(\delta^{13} \mathrm{C}\right.$ and $\left.\delta^{15} \mathrm{~N}\right)$. The reproducibility of TC and TN analysis of the atmospheric aerosol samples using the same laboratory methodology is within $2 \%$, whereas the analytical errors for $\delta^{13} \mathrm{C}$ are within $0.2 \%$ and those for $\delta^{15} \mathrm{~N}$ are $0.3 \%$ (Kawamura et al., 2004). TC and TN contents reported here were corrected for the field blank. $\delta^{13} \mathrm{C}$ and $\delta^{15} \mathrm{~N}$ values were also corrected to the field blank using isotopic mass balance equation.

\section{Results and discussion}

\subsection{TC and TN and their isotopic composition}

TC in the aerosols ranged from 0.24 to $5.88 \mu \mathrm{g} \mathrm{m}^{-3}$ with an average of $1.06 \mu \mathrm{g} \mathrm{m}^{-3}$ and median of $0.54 \mu \mathrm{g} \mathrm{m}^{-3}$, whereas $\mathrm{TN}$ ranged from 0.06 to $1.43 \mu \mathrm{g} \mathrm{m}^{-3}$ (av. $0.34 \mu \mathrm{g} \mathrm{m}^{-3}$, med. $0.17 \mu \mathrm{g} \mathrm{m}^{-3}$ ). Except for \#5 sample, whose sampling time is very short (ca. $1.3 \mathrm{~h}$ ) and which may be possibly influenced from continental aerosols, the average (median) concentrations of TC and TN were $0.52(0.53)$ and 0.22 $(0.17) \mu \mathrm{g} \mathrm{m}^{-3}$, respectively. The average TC concentrations in the marine aerosols are similar to the level reported for the winter aerosols (TC: $0.41-0.69 \mu \mathrm{g} \mathrm{m}^{-3}$, av. $0.58 \mu \mathrm{g} \mathrm{m}^{-3}$ ), but higher than that for spring aerosols $\left(0.24-0.43 \mu \mathrm{g} \mathrm{m}^{-3}\right.$, av. $0.32 \mu \mathrm{g} \mathrm{m}^{-3}$ ) collected at Alert (Narukawa et al., 2008). The TC values in the Arctic aerosols from Alert were reported to decline from winter (ca. $0.6 \mu \mathrm{g} \mathrm{m}^{-3}$ ) to early summer (ca. $0.1 \mathrm{~g} \mathrm{~m}^{-3}$ ) (Kawamura et al., 2010). Thus, the higher TC concentrations in the marine aerosols from the Arctic Ocean suggest that the marine aerosols are influenced by the sea-toair emissions of marine organic matter. TN concentrations in the marine aerosol samples are also higher than those (av. 0.08 , range: $0.01-0.16 \mu \mathrm{g} \mathrm{m}^{-3}$ ) reported in the continental Arctic aerosols from Alert (Kawamura et al., 2010). This again suggests that there is a contribution to aerosol TN from the ocean surface. Significant emissions of organic nitrogen from ocean surface were reported in the marine aerosols from the northern North Pacific (Miyazaki et al., 2011).

Stable carbon isotopic compositions of aerosol carbon in the marine aerosols are given in Fig. 3. The $\delta^{13} \mathrm{C}$ values are relatively small, ranging from $-24.7 \%$ to $-29.7 \%$ with an average of $-26.5 \%$. These low values suggest that the aerosol carbon may be derived from organic matter of terrestrial plant origin (Chesselet et al., 1981; Cachier et al., 1986; Kawamura et al., 2004; Narukawa et al., 2008). Because the surface waters in the Canadian Shelf of the Beaufort Sea are significantly influenced by the freshwater inflow from the Mackenzie River (Carmack et al., 2004), terrestrial organic materials are supplied to the surface ocean and then emitted 


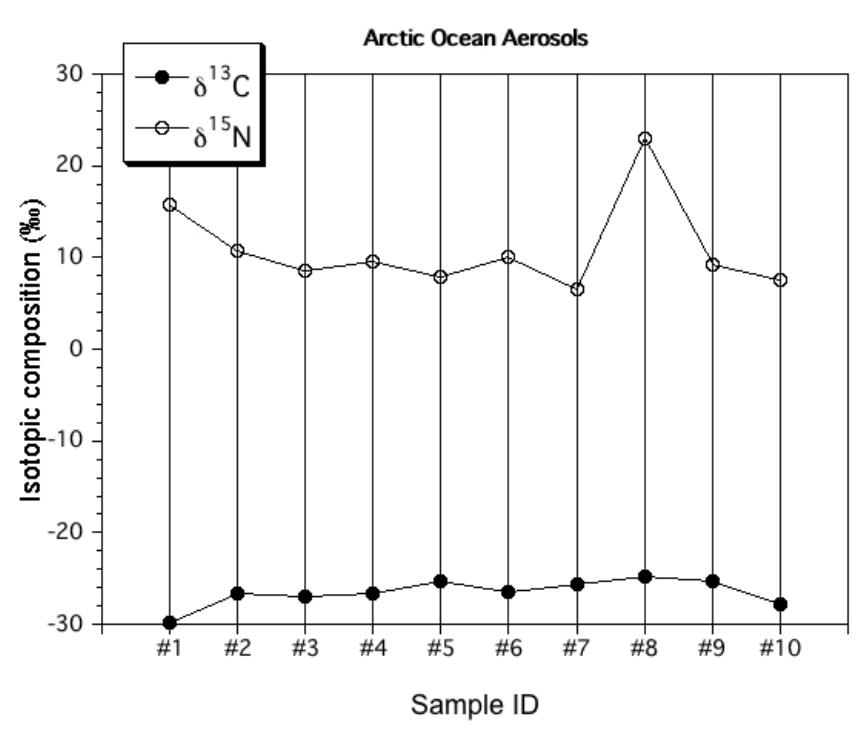

Fig. 3. Stable carbon isotopic compositions $\left(\delta^{13} \mathrm{C}\right)$ of total carbon and nitrogen isotopic compositions $\left(\delta^{15} \mathrm{~N}\right)$ of total nitrogen $(\mathrm{TN})$ in the marine aerosols from the western Arctic Ocean.

to the air by bubble bursting processes associated with wind action. In contrast, the Beaufort Sea is characterized as oligotrophic in the summertime, although primary productivity is increased during spring bloom season when sea ice melts (Carmack et al., 2004; Lavoie et al., 2009). In fact, very low $\delta^{13} \mathrm{C}$ value around $-28 \%$ was reported for the particulate organic matter (POC) in the surface water of the Canadian Basin (north of the Beaufort Sea) in the Arctic due to the inflow of terrestrial organic carbon from the Mackenzie River, although the dissolved organic carbon (DOC) showed marine signature at $-22 \%$ o (Griffith et al., 2012). However, organic materials derived from marine biological activity should also be emitted to the air, contributing to some extent to the organic aerosols. Alternatively, atmospheric transport of terrestrial organic carbon may be significant in the marine aerosols collected over the Arctic Ocean because the sampling area is close to North America.

Nitrogen isotopic composition $\left(\delta^{15} \mathrm{~N}\right)$ of total aerosol nitrogen (TN) ranged from $6.6 \%$ to $22.9 \%$ with an average of $10.9 \%$ (Fig. 3). These values are higher than those $(5.1 \pm 1.6 \%$ ) reported from the northern North Pacific (40$44^{\circ} \mathrm{N}$ ) in which contribution from marine biological activity is suggested for the aerosol organic nitrogen (Miyazaki et al., 2011). However, our values are much lower than those (15.7-31.2\%o) reported for the continental aerosols from India (Pavuluri et al., 2010) and those $(16.9 \pm 4.5 \%$ ) from marine aerosols collected at Gosan site, Jeju Island in the East China Sea (Kundu et al., 2010d). In the Asian aerosols, ammonium is the major form of aerosol nitrogen, followed by nitrate, whereas organic nitrogen is a minor fraction of TN (Kundu et al., 2010d). The significant isotopic enrichment of ${ }^{15} \mathrm{~N}$ in the Asian aerosols has been interpreted to occur during the gas-to-particle conversion $\left(\mathrm{NH}_{3} \rightarrow \mathrm{NH}_{4}^{+}\right.$, $\mathrm{HNO}_{3} \rightarrow \mathrm{NO}_{3}^{-}$) and subsequent gas/aerosol portioning of nitrogenous species (Kundu et al., 2010d; Pavuluri et al., 2010). However, low enrichment of ${ }^{15} \mathrm{~N}$ in the Arctic marine aerosols suggests that contribution of inorganic nitrogen is less important than polluted Asian aerosols; organic nitrogen may be significantly emitted from ocean surfaces by bubble bursting processes in the remote ocean (Leck and Bigg, 1999; Facchini et al., 2008; Russell et al., 2010; Miyazaki et al., 2011).

\subsection{Distributions of dicarboxylic acids, ketocarboxylic acids and $\alpha$-dicarbonyls}

In the Arctic Ocean aerosols, we detected homologous series of $\alpha, \omega$-dicarboxylic acids $\left(\mathrm{C}_{2}\right.$ - $\left.\mathrm{C}_{12}\right)$, branched chain diacids $\left(\mathrm{iC}_{4}-\mathrm{iC}_{6}\right)$, unsaturated diacids (maleic, fumaric and methylmaleic), aromatic diacids (phthalic, isophthalic and terephthalic) and hydroxy diacid (malic) as well as diacids with keto-group (ketomalonic and 4-ketopimelic). Their concentration ranges are presented in Table 1 with abbreviation for the organic species. Generally, oxalic acid $\left(\mathrm{C}_{2}\right)$ is the most abundant diacid species followed by malonic $\left(\mathrm{C}_{3}\right)$ or succinic $\left(\mathrm{C}_{4}\right)$ acid in the marine aerosols (Fig. 4), being consistent with previous studies of continental aerosols (Kawamura and Ikushima, 1993; Kundu et al., 2010c). However, we found the depletion of oxalic acid in two samples (Fig. 4), a point to be discussed in details in Sect. 3.4. We also detected ketocarboxylic acids including series of $\omega$-oxocarboxylic acids $\left(\mathrm{C}_{2}-\mathrm{C}_{9}\right)$ and pyruvic acid. Although $\omega \mathrm{C}_{6}$ was detected in the aerosols, its concentrations are not reported here because of the overlapping peak on the GC chromatogram. Among the ketoacids, 4-oxobutanoic acid $\left(\omega \mathrm{C}_{4}\right)$ was frequently found as the most abundant ketoacid (Fig. 4). This is in contrast to the previously studied aerosol samples from the low- and mid-latitudes in which glyoxylic acid $\left(\omega \mathrm{C}_{2}\right)$ is the most abundant ketoacid (Kawamura et al., 1996a; Kawamura and Yasui, 2005; Kundu et al., 2010a, c). Two $\alpha$-dicarbonyls (glyoxal and methylglyoxal) were detected in the samples. Concentrations of ketoacids and $\alpha$-dicarbonyls are roughly one and two orders magnitudes lower than those of diacids, respectively (Table 1).

The average concentrations of diacids $\left(19 \mathrm{ng} \mathrm{m}^{-3}\right)$, ketoacids $\left(2.2 \mathrm{ng} \mathrm{m}^{-3}\right)$ and $\alpha$-dicarbonyls $\left(0.4 \mathrm{ng} \mathrm{m}^{-3}\right)$ in the summer marine aerosols (Table 1) are much lower than those reported for spring aerosols from the High Arctic Alert, but are in general equivalent to those of the summer aerosols from Alert (Kawamura et al., 1996a). However, concentrations of diacids and related compounds in the summer marine aerosols from the Arctic Ocean are one or two orders magnitudes lower than those reported in summer aerosols from Gosan site in Jeju Island, the East China Sea (Kawamura et al., 2004; Kundu et al., 2010c), and are several times lower than those reported in the summer marine aerosols from the northern North Pacific (Miyazaki et al., 2011). 

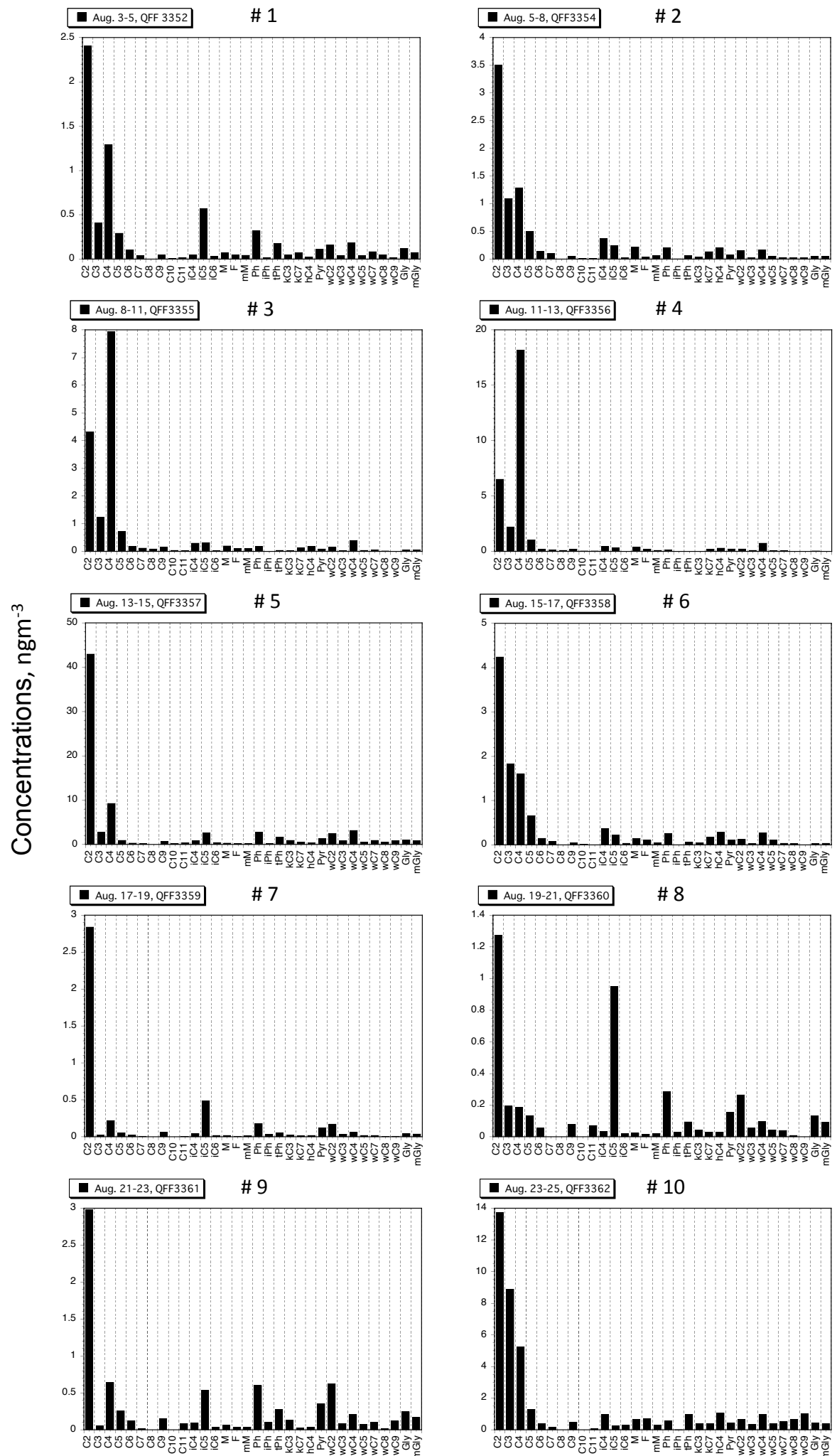

Diacids/Ketoacids/ $\alpha$-Dicarbonyls

Fig. 4. Molecular compositions of low molecular weight dicarboxylic acids $\left(\mathrm{C}_{2}-\mathrm{C}_{10}\right)$, ketocarboxylic acids $\left(\mathrm{C}_{2}\right.$ - $\left.\mathrm{C}_{9}\right)$ and $\alpha$-dicarbonyls (glyoxal and methylglyoxal) in the Arctic marine aerosols. For the details of samples \#1-\#10, see Fig. 1. For the abbreviations of compounds, see Table 1. 
Table 1. Concentrations of dicarboxylic acids, ketocarboxylic acids and $\alpha$-dicarbonyls in the marine aerosols collected over the western Arctic Ocean during MALINA cruise in August 2009.

\begin{tabular}{|c|c|c|c|c|}
\hline \multirow[t]{2}{*}{ Components, abbreviation } & \multicolumn{4}{|c|}{ Concentrations $\left(\mathrm{ng} \mathrm{m}^{-3}\right)$} \\
\hline & minimum & maximum & average & median \\
\hline \multicolumn{5}{|l|}{ Dicarboxylic acids } \\
\hline Oxalic, $\mathrm{C}_{2}$ & 1.28 & 42.99 & 8.48 & 3.87 \\
\hline Malonic, $\mathrm{C}_{3}$ & 0.13 & 8.88 & 1.91 & 1.17 \\
\hline Succinic, $\mathrm{C}_{4}$ & 0.18 & 18.18 & 4.59 & 1.44 \\
\hline Glutaric, $\mathrm{C}_{5}$ & 0.05 & 1.29 & 0.59 & 0.58 \\
\hline Adipic, $\mathrm{C}_{6}$ & 0.03 & 0.36 & 0.17 & 0.14 \\
\hline Pimelic, $\mathrm{C}_{7}$ & BDL & 0.18 & 0.09 & 0.09 \\
\hline Sebacic, $C_{8}$ & BDL & 0.11 & 0.02 & 0.00 \\
\hline Azelaic, $\mathrm{C}_{9}$ & 0.05 & 0.70 & 0.20 & 0.12 \\
\hline Decanedioic, $\mathrm{C}_{10}$ & BDL & 0.20 & 0.03 & 0.01 \\
\hline Undecanedioic, $\mathrm{C}_{11}$ & BDL & 0.40 & 0.07 & 0.04 \\
\hline Dodecanedioic, $\mathrm{C}_{12}$ & BDL & 0.14 & 0.02 & 0.00 \\
\hline Methylmalonic, $\mathrm{iC}_{4}$ & 0.04 & 0.98 & 0.35 & 0.33 \\
\hline Methylsuccinic, $\mathrm{iC}_{5}$ & 0.23 & 2.66 & 0.66 & 0.40 \\
\hline 2-Methylglutaric, $\mathrm{iC}_{6}$ & 0.02 & 0.46 & 0.10 & 0.04 \\
\hline Maleic, M & 0.02 & 0.65 & 0.21 & 0.17 \\
\hline Fumaric, F & 0.01 & 0.70 & 0.15 & 0.08 \\
\hline Methylmaleic, mM & 0.02 & 0.29 & 0.09 & 0.05 \\
\hline Phthalic, $\mathrm{Ph}$ & 0.12 & 2.80 & 0.55 & 0.27 \\
\hline Isophthalic, $\mathrm{iPh}$ & BDL & 0.22 & 0.04 & 0.02 \\
\hline Terephthalic, $\mathrm{tPh}$ & 0.04 & 1.72 & 0.35 & 0.08 \\
\hline Malic, $\mathrm{hC}_{4}$ & 0.02 & 1.05 & 0.25 & 0.19 \\
\hline Ketomalonic, $\mathrm{kC}_{3}$ & 0.02 & 0.95 & 0.17 & 0.04 \\
\hline 4-Ketopimelic, $\mathrm{kC}_{7}$ & 0.01 & 0.58 & 0.18 & 0.14 \\
\hline Subtotal & 3.57 & 69.21 & 19.28 & 9.36 \\
\hline \multicolumn{5}{|l|}{ Ketocarboxylic acids } \\
\hline Pyruvic, Pyr & 0.08 & 1.41 & 0.31 & 0.14 \\
\hline Glyoxylic (2-oxoethanoic), $\omega \mathrm{C}_{2}$ & 0.12 & 2.46 & 0.50 & 0.20 \\
\hline 3-Oxopropanoic, $\omega \mathrm{C}_{3}$ & 0.02 & 0.80 & 0.16 & 0.05 \\
\hline 4-Oxobutanoic, $\omega \mathrm{C}_{4}$ & 0.06 & 3.19 & 0.63 & 0.24 \\
\hline 5-Oxopentanoic, $\omega \mathrm{C}_{5}$ & 0.02 & 0.57 & 0.14 & 0.06 \\
\hline 7-Oxoheptanoic, $\omega \mathrm{C}_{7}$ & 0.02 & 0.98 & 0.19 & 0.06 \\
\hline 8-Oxooctanoic, $\omega \mathrm{C}_{8}$ & 0.01 & 0.66 & 0.14 & 0.03 \\
\hline 9-Oxononanoic, $\omega \mathrm{C}_{9}$ & BDL & 1.01 & 0.21 & 0.02 \\
\hline Subtotal & 0.45 & 10.82 & 2.27 & 0.76 \\
\hline \multicolumn{5}{|l|}{$\alpha$-Dicarbonyls } \\
\hline Glyoxal, Gly & 0.03 & 1.08 & 0.22 & 0.09 \\
\hline Methylglyoxal, mGly & 0.04 & 0.83 & 0.18 & 0.07 \\
\hline Subtotal & 0.07 & 1.91 & 0.40 & 0.15 \\
\hline
\end{tabular}

BDL: Below detection limit. BDL is ca. $0.005 \mathrm{ng} \mathrm{m}^{-3}$.

These comparisons indicate that the Arctic Ocean aerosols collected in the Beaufort Sea are not enriched with diacids and related compounds in the summer season, even when sea ice is mostly retreated.

To better understand the source regions of marine aerosols, backward air mass trajectories were calculated for each sampling periods (Fig. 5). It is of interest to note that, although concentrations of water-soluble organic species are low when air masses are delivered from the Arctic Ocean, we found rel- atively high abundances of diacids and related compounds in the marine aerosols when air masses arrived from the continents including North America (for example, \#3, \#4 and \#10 samples, see Figs. 4 and 5). These results suggest that the significant portion of diacids and related compounds are originated from continental sources: potential sources include polluted urban aerosols (Kawamura and Ikushima, 1993) and photochemical production from various organic precursors such as isoprene and other biogenic VOCs during long-range 

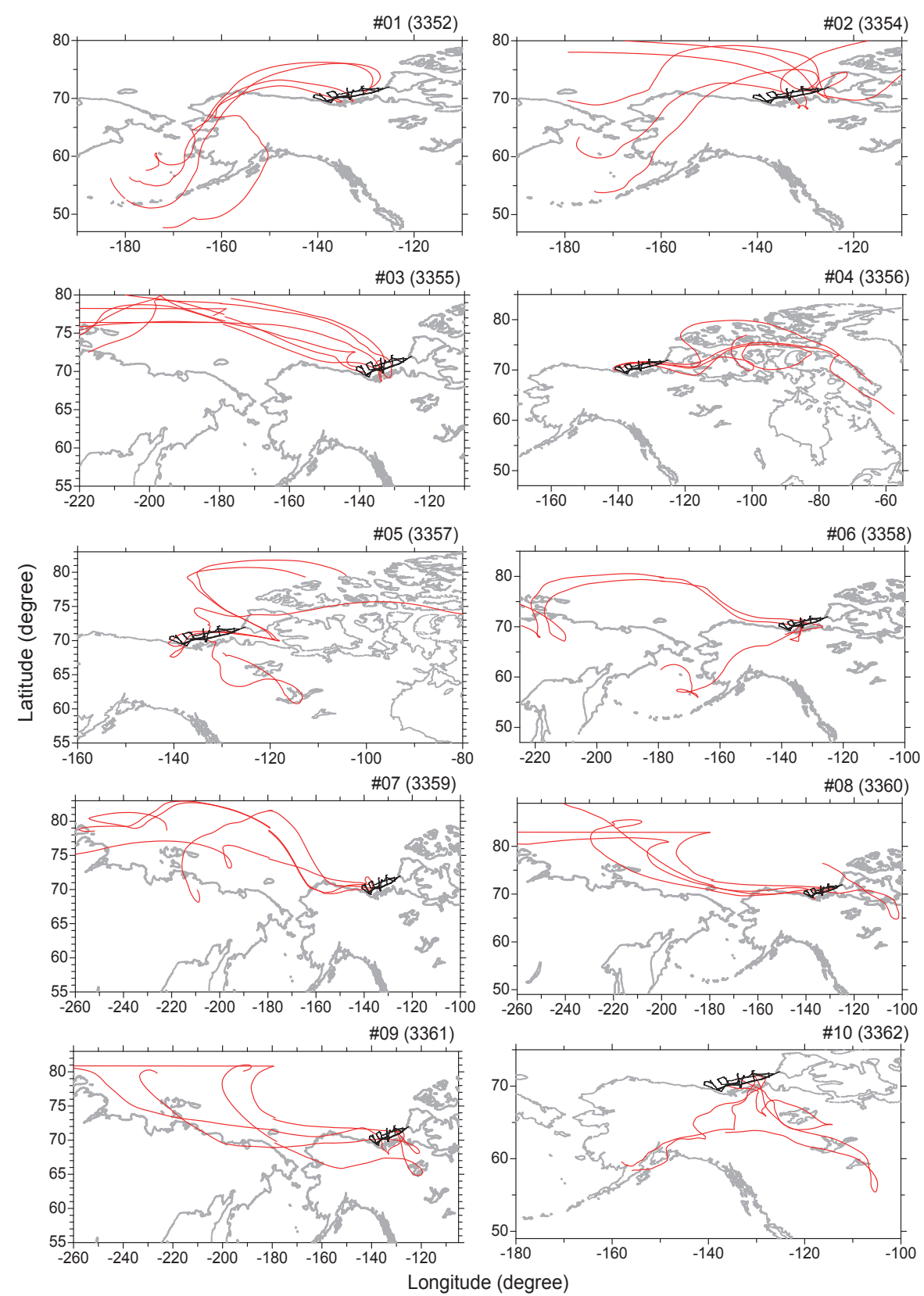

Fig. 5. Backward air mass trajectory analyses corresponding to the aerosol sample \#1 to \#10. The trajectories were calculated for seven days using the NOAA Hybrid Single-Particle Lagrangian Integrated Trajectory (Draxler and Rolph, 2003; Rolph, 2003).

atmospheric transport (Myriokefalitakis et al., 2011). One aerosol sample (\#5) showed relatively high concentrations of diacids (Fig. 4). Although the sampling period of the sample is very short (only $1.3 \mathrm{~h}$ ), the weather condition was clear. Thus, photochemically produced organic acids may have been accumulated in the marine atmosphere before and during the sampling. However, this seems unlikely because the irradiation at $412 \mathrm{~nm}$ is not very high for \#5 sample (Fig. 2) and the diacid-C/TC ratio is rather low relative to other samples (Fig. 6). Alternatively, the sampling location was very close to the coast (Fig. 1) and thus \#5 sample may have more influence from continental aerosols.

\subsection{Contributions of dicarboxylic acids, ketocarboxylic acids and $\alpha$-dicarbonyls to TC}

Figure 6 presents contributions (\%) of total diacids, ketoacids and $\alpha$-dicarbonyls to aerosol total carbon (TC). Total diacid$\mathrm{C} / \mathrm{TC}$ ratios range from 0.28 to $2.1 \%$ with an average of $0.87 \%$. These ratios are lower than those (range: $1.5-7.0 \%$, 
Table 2. Stable carbon isotopic composition (\%o) of dicarboxylic acids and ketocarboxylic acids in the marine aerosols from the Arctic Ocean in 2009.

\begin{tabular}{|c|c|c|c|c|c|c|c|c|c|c|c|c|}
\hline \multirow[b]{2}{*}{ Diacids/Ketoacids } & \multicolumn{10}{|c|}{ Sample ID, Sampling Periods } & \multirow[b]{2}{*}{ ave. } & \multirow[b]{2}{*}{ mediar } \\
\hline & $\begin{array}{c}\# 1 \\
3-5 \text { Aug }\end{array}$ & $\begin{array}{c}\# 2 \\
5-8 \text { Aug }\end{array}$ & $\begin{array}{c}\# 3 \\
\text { 8-11 Aug }\end{array}$ & $\begin{array}{c}\# 4 \\
11-13 \text { Aug }\end{array}$ & $\begin{array}{c}\# 5 \\
13-15 \text { Aug }\end{array}$ & $\begin{array}{c}\# 6 \\
15-17 \text { Aug }\end{array}$ & $\begin{array}{c}\# 7 \\
17-19 \text { Aug }\end{array}$ & $\begin{array}{c}\# 8 \\
19-21 \text { Aug }\end{array}$ & $\begin{array}{c}\# 9 \\
21-23 \text { Aug }\end{array}$ & $\begin{array}{c}\# 10 \\
23-25 \text { Aug }\end{array}$ & & \\
\hline $\begin{array}{l}\text { Oxalic, } \mathrm{C}_{2} \\
\text { Malonic, } \mathrm{C}_{3} \\
\text { Succinic, } \mathrm{C}_{4} \\
\text { Glutaric, } \mathrm{C}_{5} \\
\text { Adipic, } \mathrm{C}_{6} \\
\text { Azelaic, } \mathrm{C}_{9} \\
\text { Glycolic, } \omega \mathrm{C}_{2} \\
\text { 4-Oxobutanoic, } \omega \mathrm{C}_{4} \\
\text { Maleic, } \mathrm{M}\end{array}$ & -17 & $\begin{array}{l}-22.2 \\
-24.6 \\
-26.7 \\
-26.8\end{array}$ & $\begin{array}{c}-20.4 \\
-25.1 \\
-24 \\
-25.3\end{array}$ & $\begin{array}{c}-20.3 \\
-26.6 \\
-24 \\
-30.1\end{array}$ & -21.7 & $\begin{array}{l}-19.5 \\
-26.2 \\
-25.7 \\
-26.7\end{array}$ & -19.7 & -24.8 & -19.4 & $\begin{array}{l}-24.6 \\
-30.5 \\
-28.7 \\
-29.8 \\
-26.4 \\
-21.9 \\
-20.7 \\
-28.2\end{array}$ & $\begin{array}{l}-21.0 \\
-26.6 \\
-25.8 \\
-27.7 \\
-26.4 \\
-21.9 \\
-22.9 \\
-21.3 \\
-30.6\end{array}$ & $\begin{array}{l}-20.4 \\
-26.2 \\
-25.7 \\
-26.8 \\
-26.4 \\
-21.9 \\
-22.9 \\
-30.6\end{array}$ \\
\hline
\end{tabular}

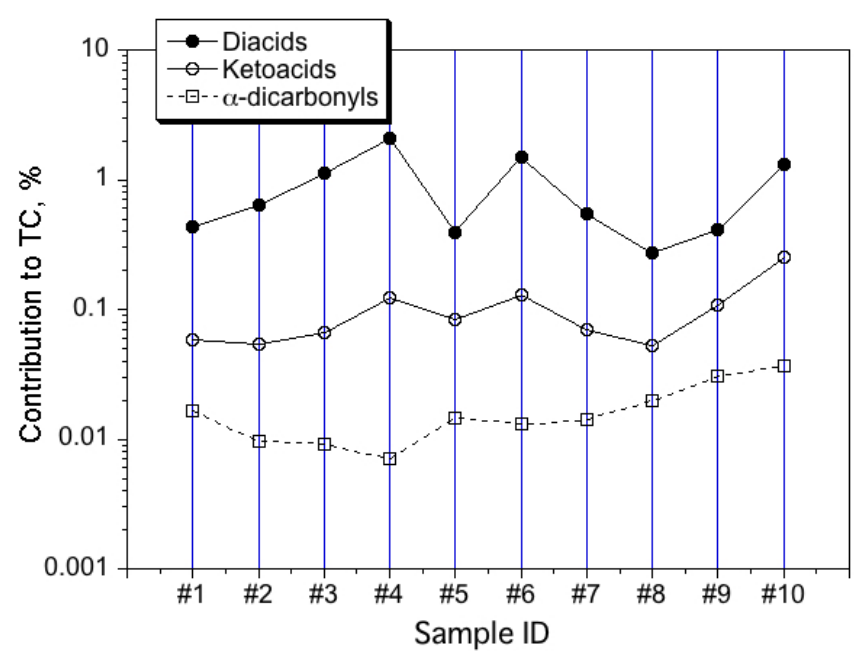

Fig. 6. Contributions of diacids, ketoacids and $\alpha$-dicarbonyls to total carbon (TC).

av. $4.0 \%$ ) reported in the Arctic aerosols from Alert during winter (February) to early summer (June) (Kawamura et al., 2010) and much lower than those (1.1-15.8\%, av. $8.8 \%$ ) reported in the remote marine aerosols collected in the North to Central Pacific including tropics (Kawamura and Sakaguchi, 1999). Unfortunately, there are no such data reported in the continental Arctic aerosols from Alert during summer. Because diacid-C/TC ratios increase with photochemical aging of organic aerosols (Kawamura and Sakaguchi, 1999), the lower values obtained during the MALINA cruise in the Arctic Ocean suggest that the marine organic aerosols are not seriously processed by photochemical oxidations. Rather, the marine aerosols may be influenced by fresh organic carbon probably emitted from the ocean surface. It is important to note that the diacid-C/TC ratios increased in samples \#3, \#4, \#6, and \#10 (Fig. 6), which were collected over the ocean when foggy and overcast conditions were observed (see Fig. 2), suggesting a production of diacids via aqueous phase oxidation of various precursors (Carlton et al., 2007; Ervens et al., 2008).
Ketocarboxylic acids were found to comprise from $0.05 \%$ to $0.26 \%$ of TC (av. $0.10 \%$ ). These values are again lower than those $(0.2-0.6 \%)$ reported for the Arctic aerosols from Alert (Kawamura et al., 2010). In contrast, the contributions of $\alpha$-dicarbonyls to TC are very small $(0.007-0.037 \%$, av. $0.017 \%)$.

\subsection{Depletion of oxalic acid: a possible aqueous phase degradation of oxalic acid under foggy conditions}

As seen in Fig. 4, molecular distributions of diacids, ketoacids and $\alpha$-dicarbonyls sometimes show unique patterns, that is, oxalic acid $\left(\mathrm{C}_{2}\right)$ is significantly depleted relative to $\mathrm{C}_{3}$ and $\mathrm{C}_{4}$ diacids in sample \#3 and \#4. Although oxalic acid is still the most abundant, its relative abundance significantly declined in samples \#6 and \#10 (Fig. 4). The apparent depletion of oxalic acid has been reported in the Arctic aerosols from Alert after polar sunrise (Kawamura et al., 2010) and more generally observed in marine aerosols collected under cold environment in the Southern Hemisphere (Sempéré and Kawamura, 2003). On the other hand, lower relative abundance of succinic acid was generally found only in aerosol samples collected under sunny and hot conditions in urban area (Kawamura and Ikushima, 1993; Sempéré and Kawamura, 1994). It is of interest to note that the depletion of oxalic acid in the marine aerosols was detected when the samples were collected under overcast conditions with fog or brume event (Fig. 2).

These meteorological conditions suggest that degradation of oxalic acid in aqueous phase of aerosols possibly in the presence of Fe may have overwhelmed its production (Kawamura et al., 2010). It was found that oxalic acid decomposes in the presence of Fe under the UV radiation in the laboratory experiment but it is stable in the absence of Fe (Pavuluri and Kawamura, 2012). Oxalic acid can form a complex with Fe (III) (iron (III)-oxalato complex) under aqueous conditions, which can photolyze under an irradiation of UV-A to visible regions to result in $\mathrm{CO}_{2}$ and $\mathrm{Fe}$ (II) (Cunningham et al., 1988; Zuo and Hoigne, 1992; Deguillaume et al., 2005). Malonic acid could also decompose in the presence of $\mathrm{Fe}$ (III) although the decomposition rate of its Fe-complex is 
ca. 20 times lower than that of oxalic acid (Faust and Zepp, 1993). Foggy conditions together with solar irradiation probably accelerate the decomposition of oxalic acid and possibly malonic acid in aqueous phase of aerosols. Although Fe concentrations were not measured in our samples, they were reported to range from $<10 \mathrm{ng} \mathrm{m}^{-3}$ to more than $100 \mathrm{ng} \mathrm{m}^{-3}$ in the Arctic aerosols from Alert during August 1980-2000 (Gong and Barrie, 2005). These concentrations are equivalent to or higher than those of oxalic acid in our aerosol samples (Table 1). Hence, the abundances of $\mathrm{Fe}$ are enough to promote the degradation reactions of oxalic acid in aerosol phase (Faust and Zepp, 1993).

\subsection{Stable carbon isotopic composition of individual diacids and ketoacids}

Table 2 presents isotopic compositions of diacids and ketoacids in the marine aerosols from the Arctic Ocean. Oxalic acid showed the largest value (av. $-21.0 \%$ ). This average value is ca. 5-6\%o higher than those of other diacids except for $\mathrm{C}_{9}$, whose isotope ratio is $-21.9 \%$, although there is only one measurement. The larger $\delta^{13} \mathrm{C}$ value of oxalic acid than malonic and succinic acids have been reported for the remote marine aerosols from the Pacific Ocean (Wang and Kawamura, 2006), the suburban aerosols from Sapporo, Japan (Aggarwal and Kawamura, 2008) and urban aerosols from India (Pavuluri et al., 2011). The present results on $\delta^{13} \mathrm{C}$ values of oxalic acid are consistent with those of aged organic aerosols. Thus, it is likely that oxalic acid in the marine aerosols is photochemically aged and its isotope ratios are increased by isotopic fractionation during the selective breakdown of ${ }^{12} \mathrm{C}-{ }^{12} \mathrm{C}$ bond of oxalic acid over the ${ }^{13} \mathrm{C}-{ }^{12} \mathrm{C}$ bond, resulting in larger $\delta^{13} \mathrm{C}$ value for remaining oxalic acid. This kind of isotopic enrichment of ${ }^{13} \mathrm{C}$ in oxalic acid has been demonstrated in the laboratory experiment of iron catalyzed photolysis of oxalate-Fe complex in aqueous phase (Pavuluri and Kawamura, 2012).

Larger isotopic ratios were seemingly obtained in samples \#3, \#4 and \#6, in which oxalic acid is depleted relative to $\mathrm{C}_{3}$ and $\mathrm{C}_{4}$ diacids as discussed above. These samples were collected during foggy days, suggesting that aqueous phase reaction may be responsible for the ${ }^{13} \mathrm{C}$ enrichment of oxalic acid over longer chain diacids. However, the isotopic enrichment in the Arctic Ocean is less significant compared to those (up to $-6.7 \%$ o) obtained in the low latitudes of the western Pacific (Wang and Kawamura, 2006). Although there is only one measured data for azelaic acid $\left(\mathrm{C}_{9}\right)$, its $\delta^{13} \mathrm{C}$ value is relatively large $(-21.9 \%$ o, Table 2$)$. Because $\mathrm{C}_{9}$ is a specific oxidation product of unsaturated fatty acids (Kawamura and Gagosian, 1987), azelaic acid should be formed in the marine atmosphere by the oxidation of marine phytoplanktonderived unsaturated fatty acids such as oleic $\left(\mathrm{C}_{18: 1}\right)$ and linoleic $\left(\mathrm{C}_{18: 2}\right)$ acids rather than unsaturated fatty acids of terrestrial plant origin. Fatty acids including $\mathrm{C}_{16}$ and $\mathrm{C}_{18}$ species in the leaf of terrestrial plants generally show $\delta^{13} \mathrm{C}$ value around $-30 \%$ (Matsumoto et al., 2007). This interpretation seems to be consistent with the predominance of 4oxobutanoic acid $\left(\omega \mathrm{C}_{4}\right)$ and relatively abundant presence of longer chain $\omega$-oxoacids $\left(\mathrm{C}_{5}-\mathrm{C}_{9}\right)$, which are another counterparts of the photochemical oxidation of unsaturated fatty acids (Kawamura and Gagosian, 1987).

\section{Summary and conclusions}

In the Arctic Ocean summer aerosols, we detected a series of water-soluble dicarboxylic acids, ketocarboxylic acids and $\alpha$-dicarbonyls. Their concentrations were found to be equivalent to those reported for the continental Arctic aerosols from Alert, but much lower than the marine aerosols from the northern North Pacific and the coastal marine aerosols from Southeast Asia. This study suggests the Arctic marine organic aerosols are influenced by sea-to-air emissions of marine organic materials and long-range transport of continental aerosols and their precursors, followed by photochemical processing in the atmosphere. We found a depletion of oxalic acid in the marine aerosols under foggy and cloudy conditions, which is possibly interpreted by selective degradation of oxalate-Fe complex in aqueous phase.

Stable carbon and nitrogen isotopic composition of the Arctic marine aerosols suggested that the sea-to-air emissions of particulate organic materials in the surface water are important sources of the marine aerosols in the west Arctic Ocean, although terrestrial organic matter is significantly supplied to the surface ocean by the Mackenzie River. Molecular distributions of diacids and related compounds also suggested the sea-to-air emissions of plankton-derived unsaturated fatty acids followed by atmospheric oxidation. However, isotopic compositions of oxalic acid suggested that photochemical aging is not as serious as the marine aerosols studied in the lower latitudes, including tropics.

Further studies are needed to better understand the source and formation/destruction pathways of dicarboxylic acids and related organic species in the Arctic marine aerosols. Global warming and the environmental changes such as sea ice retreat in the Arctic Ocean may modify the Arctic aerosol concentrations and compositions, altering the radiative budget in the Arctic.

Acknowledgements. This study is in part supported by the Japanese Ministry of Education, Science, Sport and Culture (grant-in-aid No. 19204055), and by the Environment Research and Technology Development Fund (B-0903) of the Ministry of the Environment, Japan. We appreciated the help of Osamu Seki and Yuzo Miyazaki for the shipping of the samplers. We also acknowledge Yuzo Miyazaki and Nanami Kanda for their help in drawing air mass trajectories. This study was conducted as part of the Malina Scientific Program funded by ANR (Agence Nationale de la Recherche), INSU-CNRS (Institut National des Sciences de l'Univers - Centre National de la Recherche), CNES (Centre National d'Études Spatiales) and ESA (European Space Agency). We are grateful to 
M. Babin (PI of the Malina Project) as well as the captain and crews of the Canadian Icebreaker CCGS Amundsen. Special thanks are acknowledged to Julien Para for his help during aerosol sampling.

Edited by: S. Belanger

\section{References}

Aggarwal, S. G. and Kawamura, K.: Molecular distributions and stable carbon isotopic compositions of dicarboxylic acids and related compounds in aerosols from Sapporo, Japan: Implications for photochemical aging during long-range atmospheric transport, J. Geophys. Res.-Atmos., 113, D14301, doi:10.1029/2007jd009365, 2008.

Barrie, L. A.: Arctic air pollution: an overview of current knowledge, Atmos. Environ., 20, 643-663, 1986.

Barrie, L. A.: Arctic tropospheric chemistry: an overview, Tellus B, 49, 450-454, 1997.

Cachier, H., Buat-Menard, P. M., Fontugne, M., and Chesselet, R.: Long-range transport of continentally-derived particulate carbon in the marine atmosphere: Evidence from stable carbon isotope studies, Tellus B, 38, 161-177, 1986.

Carlton, A. G., Turpin, B. J., Altieri, K. E., Seitzinger, S., Reff, A., Lim, H. J., and Ervens, B.: Atmospheric oxalic acid and SOA production from glyoxal: Results of aqueous photooxidation experiments, Atmos. Environ., 41, 7588-7602, 2007.

Carmack, E. C., Macdonald, R. W., and Jasper, S.: Phytoplankton productivity on the Canadian Shelf of the Beaufort Sea, Mar. Ecol.-Prog. Ser., 277, 37-50, 2004.

Chesselet, R., Fontugne, M., Buatmenard, P., Ezat, U., and Lambert, C. E.: The origin of particulate organic-carbon in the marine atmosphere as indicated by its stable carbon isotopic composition, Geophys. Res. Lett., 8, 345-348, 1981.

Cunningham, K. M., Goldberg, M. C., and Weiner, E. R.: Mechanisms for aqueous photolysis of adsorbed benzoate, oxalate, and succinate on iron oxyhydroxide (goethite) surfaces, Environ. Sci. Technol., 22, 1090-1097, 1988.

Deguillaume, L., Leriche, M., Desboeufs, K., Mailhot, G., George, C., and Chaumerliac, N.: Transition metals in atmospheric liquid phases: Sources, reactivity, and sensitive parameters, Chem. Rev., 105, 3388-3431, 2005.

Draxler, R. R. and Rolph, G. D.: HYSPLIT (HYbrid Single-Particle Lagrangian Integrated Trajectory) Model access via NOAA ARL READY Website (http://www.arl.noaa.gov/ready/hysplit4.html), NOAA Air Resources Laboratory, Silver Spring, MD, 2003.

Ervens, B., Feingold, G., Frost, G. J., and Kreidenweis, S. M.: A modeling study of aqueous production of dicarboxylic acids: 1. Chemical pathways and speciated organic mass production, J. Geophys. Res.-Atmos., 109, D15205, doi:10.1029/2003JD004387, 2004.

Ervens, B., Carlton, A. G., Turpin, B. J., Altieri, K. E., Kreidenweis, S. M., and Feingold, G.: Secondary organic aerosol yields from cloud-processing of isoprene oxidation products, Geophys. Res. Lett., 35, L02816, doi:10.1029/2007GL031828, 2008.

Ervens, B., Turpin, B. J., and Weber, R. J.: Secondary organic aerosol formation in cloud droplets and aqueous particles (aqSOA): a review of laboratory, field and model stud- ies, Atmos. Chem. Phys., 11, 11069-11102, doi:10.5194/acp-1111069-2011, 2011.

Facchini, M. C., Rinaldi, M., Decesari, S., Carbone, C., Finessi, E., Mircea, M., Fuzzi, S., Ceburnis, D., Flanagan, R., Nilsson, E. D., de Leeuw, G., Martino, M., Woeltjen, J., and O'Dowd, C. D.: Primary submicron marine aerosol dominated by insoluble organic colloids and aggregates, Geophys. Res. Lett., 35, L17814, doi:10.1029/2008g1034210, 2008.

Faust, B. C. and Zepp, R. G.: Photochemistry of aqueous iron(III) polycarboxylate complexes - Roles in the chemistry of atmospheric and surface waters, Environ. Sci. Technol., 27, 25172522, 1993.

Gong, S. L. and Barrie, L. A.: Trends of heavy metal components in the Arctic aerosols and their relationship to the emissions in the Northern Hemisphere, Sci. Total. Environ., 342, 175-183, 2005.

Griffith, D. R., McNichol, A. P., Xu, L., McLaughlin, F. A., Macdonald, R. W., Brown, K. A., and Eglinton, T. I.: Carbon dynamics in the western Arctic Ocean: insights from full-depth carbon isotope profiles of DIC, DOC, and POC, Biogeosciences, 9, 1217-1224, doi:10.5194/bg-9-1217-2012, 2012.

Kawamura, K.: Identification of $\mathrm{C}_{2}-\mathrm{C}_{10} \omega$-oxocarboxylic acids, pyruvic acid, and $\mathrm{C}_{2}-\mathrm{C}_{3} \alpha$-dicarbonyls in wet precipitation and aerosol samples by capillary GC and GC/MS, Anal. Chem., 65, 3505-3511, 1993.

Kawamura, K. and Gagosian, R. B.: Implications of $\omega$ oxocarboxylic acids in the remote marine atmosphere for photooxidation of unsaturated fatty acids, Nature, 325, 330-332, 1987.

Kawamura, K. and Ikushima, K.: Seasonal changes in the distribution of dicarboxylic acids in the urban atmosphere, Environ. Sci. Technol., 27, 2227-2235, 1993.

Kawamura, K. and Kaplan, I. R.: Motor exhaust emissions as a primary source for dicarboxylic acids in Los Angeles ambient air, Environ. Sci. Technol., 21, 105-110, 1987.

Kawamura, K. and Sakaguchi, F.: Molecular distributions of water soluble dicarboxylic acids in marine aerosols over the Pacific Ocean including tropics, J. Geophys. Res.-Atmos., 104, 35013509, 1999.

Kawamura, K. and Usukura, K.: Distributions of low molecular weight dicarboxylic acids in the North Pacific aerosol samples, J. Oceanogr., 49, 271-283, 1993.

Kawamura, K. and Watanabe, T.: Determination of stable carbon isotopic compositions of low molecular weight dicarboxylic acids and ketocarboxylic acids in atmospheric aerosol and snow samples, Anal. Chem., 76, 5762-5768, 2004.

Kawamura, K. and Yasui, O.: Diurnal changes in the distribution of dicarboxylic acids, ketocarboxylic acids and dicarbonyls in the urban Tokyo atmosphere, Atmos. Environ., 39, 1945-1960, 2005.

Kawamura, K., Kasukabe, H., and Barrie, L. A.: Source and reaction pathways of dicarboxylic acids, ketoacids and dicarbonyls in arctic aerosols: One year of observations, Atmos. Environ., 30, 1709-1722, 1996a.

Kawamura, K., Sempéré, R., Imai, Y., Fujii, Y., and Hayashi, M.: Water soluble dicarboxylic acids and related compounds in Antarctic aerosols, J. Geophys. Res.-Atmos., 101, 18721-18728, $1996 b$.

Kawamura, K., Kobayashi, M., Tsubonuma, N., Mochida, M., Watanabe, T., and Lee, M., Organic and inorganic compositions of marine aerosols from East Asia: Seasonal variations of water- 
soluble dicarboxylic acids, major ions, total carbon and nitrogen, and stable $\mathrm{C}$ and $\mathrm{N}$ isotopic composition, in: Geochemical Investigations in Earth and Space Science: A Tribute to Isaac R. Kaplan, edited by: Hill, R. J., Leventhal, J., Aizenshtat, Z., Baedecker, M. J., Claypool, G., Eganhouse, R., Goldhaber, M., and Peters, K., The Geochemical Society, Publication No. 9, 2004.

Kawamura, K., Imai, Y., and Barrie, L. A.: Photochemical production and loss of organic acids in high Arctic aerosols during longrange transport and polar sunrise ozone depletion events, Atmos. Environ., 39, 599-614, 2005.

Kawamura, K., Kasukabe, H., and Barrie, L. A.: Secondary formation of water-soluble organic acids and $\alpha$-dicarbonyls and their contributions to total carbon and water-soluble organic carbon: Photochemical aging of organic aerosols in the Arctic spring, J. Geophys. Res.-Atmos., 115, D21306 doi:10.1029/2010jd014299, 2010.

Kitanovski, Z., Grgic, I., and Veber, M.: Characterization of carboxylic acids in atmospheric aerosols using hydrophilic interaction liquid chromatography tandem mass spectrometry, J. Chromatogr. A, 1218, 4417-4425, 2011.

Kundu, S., Kawamura, K., Andreae, T. W., Hoffer, A., and Andreae, M. O.: Molecular distributions of dicarboxylic acids, ketocarboxylic acids and $\alpha$-dicarbonyls in biomass burning aerosols: implications for photochemical production and degradation in smoke layers, Atmos. Chem. Phys., 10, 2209-2225, doi:10.5194/acp-10-2209-2010, 2010a.

Kundu, S., Kawamura, K., Andreae, T. W., Hoffer, A., and Andreae, M. O.: Diurnal variation in the water-soluble inorganic ions, organic carbon and isotopic compositions of total carbon and nitrogen in biomass burning aerosols from the LBA-SMOCC campaign in Rondonia, Brazil, J. Aerosol Sci., 41, 118-133, 2010 b.

Kundu, S., Kawamura, K., and Lee, M.: Seasonal variations of diacids, ketoacids, and $\alpha$-dicarbonyls in aerosols at Gosan, Jeju Island, South Korea: Implications for sources, formation, and degradation during long-range transport, J. Geophys. Res.Atmos., 115, D19307, doi:10.1029/2010jd013973, 2010c.

Kundu, S., Kawamura, K., and Lee, M.: Seasonal variation of the concentrations of nitrogenous species and their nitrogen isotopic ratios in aerosols at Gosan, Jeju Island: Implications for atmospheric processing and source changes of aerosols, J. Geophys. Res.-Atmos., 115, D20305, doi:10.1029/2009jd013323, 2010d.

Lavoie, D., MacDonald, R. W., and Denman, K. L.: Primary productivity and export fluxes on the Canadian shelf of the Beaufort Sea: A modelling study, J. Marine Syst., 75, 17-32, 2009.

Leck, C. and Bigg, E. K.: Aerosol production over remote marine areas - A new route, Geophys. Res. Lett., 26, 3577-3580, 1999.

Legrand, M. and de Angelis, M.: Light carboxylic acids in Greenland ice: A record of past forest fires and vegetation emissions from the boreal zone, J. Geophys. Res.-Atmos., 101, 4129-4145, 1996.

Legrand, M., Preunkert, S., Oliveira, T., Pio, C. A., Hammer, S., Gelencser, A., Kasper-Giebl, A., and Laj, P.: Origin of $\mathrm{C}_{2}-\mathrm{C}_{5}$ dicarboxylic acids in the European atmosphere inferred from yearround aerosol study conducted at a west-east transect, J. Geophys. Res.-Atmos., 112, D23s07 doi:10.1029/2006jd008019, 2007.

Matsumoto, K., Kawamura, K., Uchida, M., and Shibata, Y.: Radiocarbon content and stable carbon isotopic ratios of individual fatty acids in subsurface soil: Implication for selective microbial degradation and modification of soil organic matter, Geochem. J., 41, 483-492, 2007.

McGuire, A. D., Anderson, L. G., Christensen, T. R., Dallimore, S., Guo, L. D., Hayes, D. J., Heimann, M., Lorenson, T. D., Macdonald, R. W., and Roulet, N.: Sensitivity of the carbon cycle in the Arctic to climate change, Ecol. Monogr., 79, 523-555, 2009.

Miyazaki, Y., Kawamura, K., Jung, J., Furutani, H., and Uematsu, M.: Latitudinal distributions of organic nitrogen and organic carbon in marine aerosols over the western North Pacific, Atmos. Chem. Phys., 11, 3037-3049, doi:10.5194/acp-11-3037-2011, 2011.

Mochida, M., Kawabata, A., Kawamura, K., Hatsushika, H., and Yamazaki, K.: Seasonal variation and origins of dicarboxylic acids in the marine atmosphere over the western North Pacific, J. Geophys. Res.-Atmos., 108, 4193, doi:10.1029/2002JD002355, 2003a.

Mochida, M., Kawamura, K., Umemoto, N., Kobayashi, M., Matsunaga, S., Lim, H. J., Turpin, B. J., Bates, T. S., and Simoneit, B. R. T.: Spatial distributions of oxygenated organic compounds (dicarboxylic acids, fatty acids, and levoglucosan) in marine aerosols over the western Pacific and off the coast of East Asia: Continental outflow of organic aerosols during the ACE-Asia campaign, J. Geophys. Res.-Atmos., 108, 8638, doi:10.1029/2002JD003249, 2003b.

Myriokefalitakis, S., Tsigaridis, K., Mihalopoulos, N., Sciare, J., Nenes, A., Kawamura, K., Segers, A., and Kanakidou, M.: In-cloud oxalate formation in the global troposphere: a 3-D modeling study, Atmos. Chem. Phys., 11, 5761-5782, doi:10.5194/acp-11-5761-2011, 2011.

Narukawa, M., Kawamura, K., Takeuchi, N., and Nakajima, T.: Distribution of dicarboxylic acids and carbon isotopic compositions in aerosols from 1997 Indonesian forest fires, Geophys. Res. Lett., 26, 3101-3104, 1999.

Narukawa, M., Kawamura, K., Li, S. M., and Bottenheim, J. W.: Dicarboxylic acids in the Arctic aerosols and snowpacks collected during ALERT 2000, Atmos. Environ., 36, 2491-2499, 2002.

Narukawa, M., Kawamura, K., Anlauf, K. G., and Barrie, L. A.: Fine and coarse modes of dicarboxylic acids in the Arctic aerosols collected during the Polar Sunrise Experiment 1997, J. Geophys. Res.-Atmos., 108, 4575, doi:10.1029/2003JD003646, 2003.

Narukawa, M., Kawamura, K., Li, S. M., and Bottenheim, J. W.: Stable carbon isotopic rations and ionic composition of the high Arctic aerosols: An increase in $\delta^{13} \mathrm{C}$ values from winter to spring, J. Geophys. Res.-Atmos., 113, D02312, doi:10.1029/2007JD008755, 2008.

Pavuluri, C. M. and Kawamura, K.: Evidence for 13-carbon enrichment in oxalic acid via iron catalyzed photolysis in aqueous phase, Geophys. Res. Lett., 39, L03802, doi:10.1029/2011g1050398, 2012.

Pavuluri, C. M., Kawamura, K., Tachibana, E., and Swaminathan, T.: Elevated nitrogen isotope ratios of tropical Indian aerosols from Chennai: Implication for the origins of aerosol nitrogen in South and Southeast Asia, Atmos. Environ., 44, 3597-3604, 2010.

Pavuluri, C. M., Kawamura, K., Swaminathan, T., and Tachibana, E.: Stable carbon isotopic compositions of total carbon, dicarboxylic acids and glyoxylic acid in the tropical Indian 
aerosols: Implications for sources and photochemical processing of organic aerosols, J. Geophys. Res.-Atmos., 116, D18307 doi:10.1029/2011jd015617, 2011.

Rohrl, A. and Lammel, G.: Low molecular weight dicarboxylic acids and glyoxylic acid: Seasonal and air mass characteristics, Environ. Sci. Technol., 35, 95-101, 2001.

Rolph, G. D.: Real-time Environmental Applications and Display sYstem (READY) Website (http://www.arl.noaa.gov/ready/ hysplit4.html). NOAA Air Resources Laboratory, Silver Spring, MD, 2003.

Rompp, A., Winterhalter, R., and Moortgat, G. K.: Oxodicarboxylic acids in atmospheric aerosol particles, Atmos. Environ., 40, 6846-6862, 2006.

Russell, L. M., Hawkins, L. N., Frossard, A. A., Quinn, P. K., and Bates, T. S.: Carbohydrate-like composition of submicron atmospheric particles and their production from ocean bubble bursting, P. Natl. Acad. Sci. USA, 107, 6652-6657, 2010.

Saxena, P. and Hildemann, L. M.: Water-soluble organics in atmospheric particles: A critical review of the literature and application of thermodynamics to identify candidate compounds, J. Atmos. Chem., 24, 57-109, 1996.

Saxena, P., Hildemann, L. M., Mcmurry, P. H., and Seinfeld, J. H.: Organics alter hygroscopic behavior of atmospheric particles, J. Geophys. Res.-Atmos., 100, 18755-18770, 1995.

Sempéré, R. and Kawamura, K.: Comparative distributions of dicarboxylic-acids and related polar compounds in snow rain and aerosols from urban atmosphere, Atmos. Environ., 28, 449-459, 1994.

Sempéré, R. and Kawamura, K.: Trans-hemispheric contribution of $\mathrm{C}_{2}-\mathrm{C}_{10} \alpha, \omega$-dicarboxylic acids, and related polar compounds to water-soluble organic carbon in the western Pacific aerosols in relation to photochemical oxidation reactions, Global Biogeochem. Cy., 17, 1069, doi:1010.1029/2002GB001980, 2003.
Sorooshian, A., Varutbangkul, V., Brechtel, F. J., Ervens, B., Feingold, G., Bahreini, R., Murphy, S. M., Holloway, J. S., Atlas, E. L., Buzorius, G., Jonsson, H., Flagan, R. C., and Seinfeld, J. H.: Oxalic acid in clear and cloudy atmospheres: Analysis of data from International Consortium for Atmospheric Research on Transport and Transformation 2004, J. Geophys. Res.-Atmos., 111, D23S45, doi:10.1029/2005JD006880, 2006.

Wang, H. B. and Kawamura, K.: Stable carbon isotopic composition of low-molecular-weight dicarboxylic acids and ketoacids in remote marine aerosols, J. Geophys. Res.-Atmos., 111, D07304, doi:10.1029/2005JD006466, 2006.

Wang, G., Niu, S., Liu, C., and Wang, L.: Identification of dicarboxylic acids and aldehyde of $\mathrm{PM}_{10}$ and $\mathrm{PM}_{2.5}$ aerosols in Nanjing, China, Atmos. Environ., 36, 1941-1950, 2002.

Warneck, P.: In-cloud chemistry opens pathway to the formation of oxalic acid in the marine atmosphere, Atmos. Environ., 37, 2423-2427, 2003.

Yao, X. H., Fang, M., and Chan, C. K.: Size distributions and formation of dicarboxylic acids in atmospheric particles, Atmos. Environ., 36, 2099-2107, 2002.

Zuo, Y. G. and Hoigne, J.: Formation of hydrogen peroxide and depletion of oxalic acid in atmospheric water by photolysis of iron (III) oxalato complexes, Environ. Sci. Technol., 26, 1014$1022,1992$. 